\title{
Interaksi Budaya dan Bahasa dalam Kehidupan Masyarakat di Indonesia
}

\author{
Ratna Nisrina Puspitasari \\ Universitas Sebelas Maret, INDONESIA \\ Email: ratna_nisrina@student.uns.ac.id
}

\begin{abstract}
This article discusses the interaction that occurs between language and culture in the life of society Indonesia. Language and culture often experience interaction in social life. Moreover, in language life and culture often interact in certain forms such as language and local wisdom, culture and language learning, language adaptation, language and culture perspectives in gender, language and culture distinguishing with world vision, language and culture discourse journalism, culture influences in the literary works, and cultural influences in the style of language and structure of friday prayer's sermon. The method used in this article is a qualitative research method. This article aims to explain the relationship between language and culture and the interaction that occurs between the two.
\end{abstract}

Keyword: culture, language, relationship, language and culture interaction

\begin{abstract}
Abstrak
Tulisan ini membahasa interaksi yang terjadi antara bahasa dan budaya dalam kehidupan masyarakat Indonesia. Bahasa dan budaya sering mengalami interaksi dalam kehidupan bermasyarakat. Selain Selain itu dalam kehidupan bermasyarakat bahasa dan budaya sering kali berinteraksi dalam bentuk bentuk tertentu antara lain bahasa dan kearifan lokal, budaya dan pembelajaran bahasa, adaptasi bahasa, perspektif bahasa dan budaya dalam distingsi gender, bahasa dan budaya dengan visi dunia, bahasa dan budaya dalam wacana jurnalistik, pengaruh budaya dalam bahasa karya sastra, dan pengaruh budaya dalam gaya bahasa dan struktur bahasa Khotbah Jumat. Metode yang digunakan dalam tulisan ini adalah penelitian kualitatif. Tulisan ini bertujuan untuk menjelaskan hubungan antara bahasa dan budaya serta interaksi yang terjadi antar keduanya.
\end{abstract}

Kata Kunci: budaya, bahasa, interaksi, bahasa dan budaya

\section{A. Pendahuluan}

Bahasa adalah sarana atau alat yang digunakan manusia untuk mengekspresikan pikiran dan perasaannya sehingga pikiran manusia dapat terpengaruhi oleh bahasa (Saddhono, 2014). Bahasa sebagai alat komunikasi yang berupa simbol bunyi yang dihasilkan dari alat ucap manusia dan digunakan sebagai alat komunikasi antar anggota masyarakat (Keraf, 2004). Selain itu, bahasa merupakan kajian mengenai struktur gramatika, yang berisi aspek bunyi, kata, dan kalimat. Sebagai sebuah kajian, bahasa adalah perwujudan dari budi manusia yang menjelma menjadi akal dan pikiran manusia (Alisyahbana, 1977). Pengaruh bahasa terhadap pikiran manusia dapat berupa pola berpikir dan gaya bicara. Hal tersebut dapat dilihat dari pola berpikir masyarakat Jawa yang cenderung membagi pemakaian bahasanya menjadi beberapa tingkat, yaitu ngoko, karma, karma inggil. Sementara di Bali, dikenal istilah sor (tingkat rendah) dan singgih (tingkat tinggi) (Saddhono, 2014).

Pembagian tingkatan bahasa oleh suatu suku ataupun etnik tertentu manandakan bahwa bahasa digunakan sebagai identitas kelompok tertentu. Bahasa selain sebagai sarana komunikasi juga seringkali dianggap sebagai sebuah jati diri dan identitas suatu suku, etnik, maupun kelompok tertentu (Sumarsono, 2007). Oleh karena itu bahasa merupakan salah satu aspek dalam kehidupan manusia yang tidak bisa lepas dari budaya. 
Budaya merupakan hasil dari akal dan ikhtisar manusia (Widyosiswoyo, 2004). Sedangkan Koentjaraningrat (2005) mendefinisikan budaya sebagai seluruh total pikiran manusia, karya manusia, dan hasil manusia yang tidak berasal dari nalurinya, dan hanya bisa dihasilkan setelah manusia melakukan proses belajar. Hal tersebut manandakan bahwa budaya menjadi salah satu tolak ukur adanya sebuah peradaban yang maju. Melalui budaya yang ada, manusia mewarisi nilai-nilai luhur yang diturunkan nenek moyangnya.

Bahasa dan budaya adalah dua unsur penting yang tidak dapat dipisahkan, keduanya saling berkaitan. Bahasa merupakan salah satu unsur dalam budaya (Koentjaraningrat, 2005). Sebaliknya, bahasa merupakan cerminan dari budaya yang ada, sifat-sifat bahasa yang dihasilkan berasal dari budaya yang membangunnya. Seperti bahasa jawa yang digunakan untuk menyalurkan nilai-nilai kearifan lokal dan pendidikan karakter dari dongeng Sayu Wiwit (Fatimah, Sulistyo, \& Saddhono, 2017).

Melalui interaksi bahasa dan budaya, banyak terlahir karya sastra yang dapat menjadi sumber pembelajaran bagi manusia. Karya sastra tersebut penuh dengan dengan muatan nilai-nilai luhur. Salah satu yang dapat dijadikan bahan pembelajaran adalah novel Nun: Pada Sebuab Cermin karya Afifah Afra. Novel tersebut sarat akan nilai-nilai sosio-budaya dan pendidikan karakter yang tercermin dalam unsur-unsur intrinsik di dalamnya.

Berbagai hal telah menunjukan bahwa bahasa dan budaya tidak dapat dipisahkan keberadaannya. Oleh karena itu dalam tulisan ini akan dipaparkan penjelasan mengenai hubungan bahasa dan budaya berserta interaksi yang terjadi antar keduanya. Dengan tulisan ini diharapkan dapat menambah pengetahuan mengenai kontak yang terjadi antara bahasa dan budaya.

\section{B. Metode Penelitian}

Metode yang digunakan dalam penelitian ini adalah deskriptif kualitatif. Penelitian kualitatif ini berdasarkan objek penelitian yang diperoleh dari data observasi, yaitu interaksi bahasa dan budaya dalam masyarakat Indonesia. Masalah difokuskan pada interaksi yang terjadi antara bahasa dan budaya. Sumber data yang digunakan adalah dokumen hasil observasi dan kajian pustaka. Data yang telah diperoleh dari hasil observasi kemudian dideskripsikan dan dianalisis (Santana, 2007).

Analisis data dilakukan bersamaan dengan proses pelaksanaan pengumpulan data. Penelitian ini terdiri atas tiga komponen pokok yang saling berinteraksi dan berkaitan. Proses analisis data menggunakan model analisis interaktif dan model analisis dokumentatif. Data-data yang diperoleh kemudian dibandingkan dan dianalisis secara komprehensif.

\section{Pembahasan}

\section{Hubungan Bahasa dan Budaya}

Bahasa merupakan produk kebudayaan yang tidak bisa terpisahkan (Koentjaraningrat, 2005). Bahasa tidak ada bedanya dengan makhluk hidup yang lain, karena bahasa juga mengalami lahir, kecil, lalu berkembang menjadi dewasa dan sirna (Abusyairi, 2003). Jadi bahasa tidak statis seperti yang sering diasumsikan kebanyakan orang.

Budaya merupakan sebuah kajian yang bersifat kompleks, abstrak, dan luas (Mulyana \& Rakhmat, 2006). Budaya disebut sebagai pola hidup yang menyeluruh. Unsur-unsur sosio-budaya banyak tersebar dalam berbagai kegiatan sosial masyarakat. Dari penjelasan tersebut diperoleh kesimpulan bahwa budaya adalah suatu sistem pengetahuan yang meliputi sistem ide dan pikiran manusia dan merupakan cermin yang lengkap dan sempurna dari budaya (Alisyahbana, 1977).

Peran bahasa sangat penting bagi kebudayaan karena bahasa mempunyai peran dominan dalam perkembangan kebudayaan (Mardikantoro, 2013). Sependapat dengan Mardikantoro, Masinambouw 
(2000) menyatakan bahwa bahasa menempati kedudukan yang sentral dan penting dalam kehidupan manusia karena bahasa mempunyai aspek majemuk yang meliputi aspek biologis, psikologis, sosial, dan kultural. Oleh karena itu, bahasa dan budaya adalah dua hal yang tidak dapat dipisahkan karena keduanya mempunyai hubungan yang sangat erat dan saling memengaruhi antar satu dengan lainnya (Abusyairi, 2013). Dalam berbahasa hendaknya memperhatikan norma-norma yang berlaku dalam sistem budaya di mana bahasa tersebut digunakan.

Bahasa dan budaya dalam sebuah daerah atau wilaya mempunyai interaksi yang beragam. Keduanya salig berhubungan tanpa disadari oleh masyarakat. Masyarakat cenderung berpikir bahwa bahasa dan budaya adalah kedua hal yang terpisah dan tidak berhubungan. Padahal keduanya adalah salah satu faktor yang dapat mengukur atau barometer bagi sebuah peradaban yang diciptakan dan diabngun oleh manusia. Melalui bahasa dan budaya, generasi mendatang dapat mengetahui perkembangan dan pertumbuhan peradaban di masa lalu. Dengan demikian dapat disimpulkan bahwa bahasa dan budaya selalu mempunyai hubungan yang harmonis dalam setiap peradaban manusia.

\section{Interaksi Antara Bahasa dan Budaya}

Terdapat berbagai macam interaksi yang sering terjadi antara bahasa dan budaya, antara lain:

Bahasa dan Kearifan Lokal

Bahasa digunakan sebagai sarana dalam mengungkapkan kearifan lokal. Selain sebagai sarana, bahasa juga digunakan sebagai media untuk mentransfer kearifan lokal yang sudah ada ke generasi berikutnya dan menyebarkan kearifan lokal daerah tertentu ke daerah lain. Hal ini berdasarkan penelitian Mardikantoro (2013) yang mengungkapkan bahwa kearifan lokal dari Suku Samin diungkapkan melalui bahasa Jawa. Cara yang digunakan untuk mengungkapkan kearifan lokal secara lingual adalah dalam bentuk kata, kalimat, dan wacana. Kearifan lokal yang diungkapkan dalam bahasa Jawa meliputi (1)Ajaran tentang hawa nafsu, (2)Ajaran agar tidak berbuat jahat, (3)Ajaran tentang larangan menyakiti orang lain, (4)Ajaran tentang panutan hidup, (5)Ajaran tentang memegang teguh ucapan, (6)Ajaran tentang hukum karma, (7)Ajaran tentang kejujuran, (8)Ajaran tentang hal yang mustahil, (9)Ajaran tentang hak milik dan istri, (10)Ajaran tentang berbakti pada orang tua, (11)Ajaran tentang melestarikan lingkungan, dan (12)Ajaran tentang etika kerja

Budaya dan Pembelajaran Bahasa

Budaya dalam hal ini menjadi sebuah pendekatan yang digunakan dalam pembelajaran bahasa. Hal ini berdasarkan pada penelitian Abusyairi (2013) yang menjelaskan bahwa penguasaan bahasa yang baik dalam komunikasi bukan hanya karena pengaruh penguasaan linguistik namun juga dipengaruhi oleh pemahaman bahasa sesuai dengan konteks, sehingga diperlukan pemahaman terhadap budaya penutur. Sebagai contoh adalah hasil penelitiannya mengenai pelaksanaan penanaman muatan budaya dalam pembelajaran bahasa Arab yang diintegrasikan dalam tahapan berikut (1)Materi pembelajaran, (2)Seleksi dan pengorganisasian diri, (3)Metode pembelajaran dengan pendekatan budaya, dan (4)Evaluasi.

Penelitian serupa pernah dilakukan oleh Saddhono (2015) melalui proses pembelajaran bahasa Indonesia bagi penutur asing (BIPA). Dalam penelitian tersebut pembelajaran BIPA banyak dipengaruhi oleh berbagai faktor salah satunya adalah budaya asal dari penutur asing tersebut. Bahasa dan budaya penutur asing mengambil peranan yang cukup besar dalam proses pembelajaran.

Adaptasi Bahasa

Adaptasi bahasa sering dijumpai dalam berbagai kesempatan, baik dalam bentuk lisan maupun tulis. Namun dalam melakukan adaptasi bahasa atau sering mudah disebut penerjemaham bahasa tertentu ke dalam bahasa yang lain perlu melihat latar belakang budaya dari bahasa yang akan diterjemahkan. Makna dan arti yang diterjemahkan akan berbeda jika seorang penerjemah mengabaikan latar belakang budaya dari bahsasa tersebut. 
Seperti dalam budaya inventori Big Five. Big Five adalah taksonomi kepribadian yang disusun berdasarkan pengelompokan kata-kata atau bahasa yang digunakan dalam kehidupan sehari-hari, untuk membedakan ciri individu satu dengan lainnya (Ramdhani, 2012). Berdasarkan penelitian, untuk meningkatkan presentase aitem yang memenuhi kriteria sesuai dengan konstruk maka proses penerjemahan alat ukur psikologi yang disusun dan dikembangkan dari negara lain harus dilakukan tidak hanya dengan menerjemahkan bahasanya saja tetapi harus disesuaikan dengan budaya dari bangsa di mana bahasa itu digunakan (Ramdhani, 2012). Hal tersebut karena suatu pertanyaan untuk mengungkapkan persepsi orang yang berbahasa ibu bahasa Inggris dapat dimaknai berbeda dengan orang yang berbahasa ibu bahasa Indonesia.

Perspektif Bahasa dan Budaya dalam Distingsi Gender

Berdasarkan penelitian penanda gender mempunyai perbedaan berdasarkan latar belakang budayanya. Sistem gender di Arab hampir semua terdapat dalam semua kelas kata (Nur, 2011). Distingsi gender yang ketat dan terperinci antara maskulin dan feminim karena diwakili oleh ungkapan-ungkapan maskulin untuk feminim yang menggambarkan kuatnya budaya patriarkat dalam masyarakat Arab. Budaya patriarkat adalah budaya budaya sisilah yang mengutamakan garis keturunan laki-laki berdasarkan sistem patrilineal. Nama-nama kabilah atau suku diambil dari garis keturunan laki-laki yang ditandai dengan bin dan binti.

Berbeda halnya dengan Indonesia yang menganut sistem gender yang longgar. Artinya, pembedaan maskulin dan feminim hanya dibatasi pada kelas kata nomina dan adjektiva sedangkan dalam bahasa Arab ditandai secara fonemis, morfemis, dan dan leksikal. Hal ini karena Indonesia menganut sistem gotong royong dan kolektivitas sehingga tidak memandang jenis kelamin sebagai sesuatu yang harus dibedakan secara ketat namun lebih menakankan pada perbedaan umur dan status bukan menekankan jenis kelamin.

Perspektif bahasa dan budaya dalam distingsi gender di setiap daerah maupun negara mempunyai keunikan masing-masing. Setiap daerah maupun negara mempunyai aturan tidak tertulis dalam distingsi gender. Salah satu yang dapat menjadi penanda adalah melaui perspektif bahasa dan budaya. Hal tersebut karena keduanya dapat diamati secara langsung tanpa kajian yang rumit.

Bahasa dan budaya dengan visi dunia.

Bahasa, budaya, dan pikiran mempunyai keterkaitan yang sangat erat kaitannya dengan visi dunia sebagai unsur yang mendasari (Nadaek, 2008). Hal tersebut karena budaya merupakan bagian integral dari interaksi antara bahasa dan pikiran. Perlu dicatat bahwa perbedaan antara bahasa yang ada disebabkan oleh perbedaan visi dunia. Pola-pola yang ada pada budaya, adat, dan cara hidup diungkapkan dan diekspresikan dalam bahasa. Oleh karena itu, secara keseluruhan sistem bahasa mengandung suatu visi dunia yang oleh penuturnya diterima dan diproyeksikan ke dalam realitas.

Hal serupa pernah diterapkan oleh negara-negara seperti Jerman, Jepang, dan Italia yang mencoba menyebarkan doktrin dan visi mereka melalui bahasa semboyan mereka. Melalui semboyan itulah ketiga bangsa tersebut berusaha mencapai supremasi tetinggi bangsa mereka. Semboyan yang mereka punya ingin coba direalisasikan secara konkret dan nyata.

Bahasa dan Budaya dalam Wacana Jurnalistik

Berdasarkan hasil penelitian Arief (2010) menunjukan bahwa insklusifitas karakteristik nilai budaya Indonesia yang ditemukan dalam aspek makro subaspek tematisasi dan struktur tematis WJBBI (wacana jurnalistik berita bahasa indonesia) adalah (1)Teohumanistis, (2)Kosmosentris, (3)Harmoni, (4)Kolektivisme, (5)Eksklusifitas antara kharismatisme dan rasionalisme, (6)Pragmatism, dan (7)Atomisasi religiositas dan filosofi.

Inklusifitas persepsi budaya Indonesia yang ditemukan dalam aspek superstruktur subaspek pola kontekstualisasi dan pola realisasi WJBBI adalah (1)Perpsepsi terhadap suatu informasi, (2)Persepsi 
terhadap isu dan orang yang menyebarkannya, (3)Persepsi terhadap tugas dan relasi, (4)Persepsi terhadap kelogisan kalimat, (5)Persepsi terhadap gaya komunikasi, (6)Persepsi terhadap pola negosiasi, (7)Persepsi terhadap informasi tentang individu, (8)Persepsi terhadap bentuk pesan, (9)Persepsi terhadap suatu fakta, (10)Persepsi terhadap in group dan out group, (11)Persepsi terhadap pertalian antar-individu, dan (12)Persepsi terhadap waktu.

Pengaruh Budaya dalam Bahasa Karya Sastra

Bahasa sebuah karya sastra sering dipengaruhi oleh latar belakang budaya dari penulis. Hal ini berdasarkan penelitian Suprani (2013) menjelaskan bahwa cerita yang dimuat dalam surat kabar Pikiran Rakyat (periode Januari sampai April 2010) dan Kompas (periode Mei sampai Agustus 2010) bahasa yang ada di dalamnya dipengaruhi oleh nilai-nilai tradisi budaya Banten. Sehingga dapat disimpulkan bahwa karya sastra sering dipengaruhi oleh latar belakang budaya penulisnya. Penelitian serupa juga pernah dilakukan Trianton, Suwandi, Waluyo, \& Saddhono (2016) yang menyatakan bahwa novel karya Ahmad Tohari memuat keraifan lokal dari Banyumas. Hal serupa coba diungkapkan oleh (Setyawan, Saddhono, \& Rakhmawati, 2017) yang menyatakan naskah ketoprak di Surakarta brebeda gaya dengan naskah ketoprak di daerah lain karena situasi sosial budaya.

Pengaruh Budaya dalam Gaya Bahasa dan Struktur Bahasa Khotbah Jumat

Latar belakang budaya memengruhi struktur dan gaya bahasa dan struktur bahasa khotbah jumat. Gaya bahasa dan struktur bahasa khotbah jumat di setiap daerah berbeda-beda. Khotbah jumat di Jawa dan pulau Madura dianggap sebagai salah satu bagian dari ritual salat jumat yang sakral dan suci. Penelitian sebelumnya mengenai khotbah jumat telah banyak dilakukan oleh Saddhono (2010, 2011, 2012, 2013, 2015). Penelitian yang telah dilakukan sebelumnya selalu berpusat pada khotbah jumat.

Berdasarkan penelitian-penelitian tersebut salah satunya membahas bahwa budaya menyebabkan adanya perbedaan struktur bahasa dalam khotbah jumat.

\section{Penutup}

Disimpulkan bahwa bahasa dan budaya mempunyai hubungan erat yang tidak dapat dipisahkan karena saling berkaitan. Selain itu dalam kehidupan bermasyarakat bahasa dan budaya sering kali berinteraksi dalam bentuk bentuk tertentu antara lain bahasa dan kearifan lokal, budaya dan pembelajaran bahasa, adaptasi bahasa, perspektif bahasa dan budaya dalam distingsi gender, bahasa dan budaya dengan visi dunia, bahasa dan budaya dalam wacana jurnalistik, pengaruh budaya dalam bahasa karya sastra, dan pengaruh budaya dalam gaya bahasa dan struktur bahasa Khotbah Jumat. Oleh karena itu dalam kehidupan bermasyarakat bahasa dan budaya selalu beriringan dan saling berinterakasi dalam berbagai bentuk dan bidang.

\section{Daftar Pustaka}

Abusyairi, K. (2013). Pembelajaran Bahasa dengan Pendekatan Budaya. Dinamika Ilmu: Jurnal Pendidikan, 13(2).

Alisyahbana, S.T. (1977). Dari Perjuangan dan Pertumbuhan Bahasa Indonesia dan Babasa Melayu sebagai Bahasa Modern (Kumpulan Esai 1957 - 1877). Jakarta: Dian Rakyat.

Arief, N.F. (2010). Eksplanasi Inklusifitas Bahasa dan Budaya Indonesia dalam Wacana Jurnalistik. LITERA, 9(2), 182-189.

Fatimah, F.N., Sulistyo, E.T., \& Saddhono, K.(2017). Lokal Wisdom Value in Sayu Wiwit Folklore As The Revitalization of Behavioral Education. Karsa: Journal of Social and Islamic Culture, 25(1), 179-199. 
Keraf, G.(2004). Komposisi Sebuah Pengantar Kemabiran Bahasa. Flores: Nusa Indah.

Koentjaraningrat.(2005). Pengantar Antropologi. Jakarta: Rineka Cipta.

Mardikantoro, H. B. (2013). Bahasa Jawa Sebagai Pengungkap Kearifan Lokal Masyarakat Samin Di Kabupaten Blora. Komunitas: International Journal Of Indonesian Society And Culture, 5(2), 197207.

Masinambow, E.K.M.(2000).Kajian serba Linguistik untuk Anton Moeliono Pereksa Bahasa. Jakarta: Gunung Mulia dalam kerja sama dengan Universitas Katolik Indonesia Atma Jaya.

Mulyana, D. \& Rakhmat, J.(2006). Komunikasi Antarbudaya: Panduan Berkomunikasi dengan Orang-Orang Berbeda Budaya. Bandung: Remaja Rosdakarya.

Nadaek, P.(2008). Pengajaran Bahasa dan Visi Dunia: Sebagai Komunikasi Lintas Budaya, Jurnal Cakrawala Kependidikan, 6(2), 132-143.

Ramdhani, N. (2012). Adaptasi Bahasa dan Budaya dari Skala Kepribadian Big Five. Jurnal Psikologi, 39(2), 189-205.

Santana, S. (2007). Menulis Ilmiah: Metode Penelitian Kualitatif. Jakarta: Yayasan Obor Indonesia.

Setyawan, B.W, Saddhono, K., \& Rakhmawati, A.(2017). Sociological Aspects and Lokal Specificity in the Classical Ketoprak Script of Surakarta Style. Journal of Language and Literature, 17(2),144151.

Saddhono, K. (2015). Integrating Culture in Indonesian Language Learning for Foreign Speakers at Indonesian Universities. Journal Language and Literature, 6(2), 349-353.

Saddhono, K, Wardani, N.E., Ulya, C. (2015). Sociopragmatic Approach On Discourse Structure of Friday Prayer's Sermon In Java And Madura Island. Journal of Language Literature, 6(1), 2630.

Saddhono, K. (2013). The Friday Sermon In Surakarta: Sociopragmatic Studies. Journal of the Humanities of Indonesia, 15(1), 145-150.

Saddhono, K. (2014). Pengantar Sosiolinguistik: Teori dan Konsep Dasar. Surakarta: Sebelas Maret University Press.

Saddhono, K. (2012). Bentuk dan Fungsi Kode Dalam Wacana Khotbah Jumat: Studi Kasus di Kota Surakarta. Jurnal Adabiyyat, 11(1), 71-80.

Saddhono, K., Wijana, I. D. P. (2011). Wacana Khotbah Jumat di Kota Surakarta: Sebuah Kajian Linguistik Kultural. Jurnal Pendidikan dan Kebudayaan, 17(4), 433-446.

Saddhono, K. \& Poedjosoerdarmo, S. (2010). Wacana Khotbah Jumat Sebagai Pengembangan Bahan Ajar Mata Kuliah "Analisis Wacana" di Perguruan Tinggi". Jurnal Akademika, 2(1), 40-48.

Sumarsono \& Partana, P. (2007). Sosiolinguistik. Yogyakarta: Sabda.

Suprani. (2013). Pesan Moral dan Nilai Budaya Banten Dalam Cerpen Anak Pada Surat Kabar Pikiran Rakyat Dan Kompas Sebagai Pengembangan Sarana Pembelajaran Bahasa Dan Sastra Indonesia di Kelas VII SMPN 6 Kota Tangerang. Jurnal Pendidikan Dan Pembelajaran, 20(1), 53-65.

Trianton, T., Suwandi, S., Waluyo, H.J., \& Saddhono, K.. (2016). Ethics Values As The Portrayal of Banyumas Local Wisdoms in The Novels of Ahmad Tohari. International Journal of Languages Education and Teaching, 4(3), 306-319 
Widyosisw oyo. (2004). Ilmu Budaya Dasar. Jakarta: Ghalia Indonesia. 